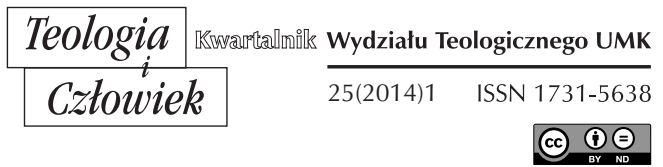

KS. CZESŁAW KRAKOWIAK*

\title{
PAWŁA VI KONSTYTUCJA APOSTOLSKA O SAKRAMENCIE NAMASZCZENIA CHORYCH
}

Przyjęta przez II Sobór Watykański Konstytucja o liturgii (4 XII 1963) zwiera nie tylko naukę Kościoła o istocie i znaczeniu liturgii, ale również ogólne wskazania dotyczące jej odnowy w duchu sana traditio et progressio. Nowe formy i elementy liturgii można wprowadzać jedynie wtedy, gdy jest to konieczne. Mają one „niejako organicznie wyrastać z form już istniejących" (KL 23), aby zachować istotę obrządku rzymskiego i nie tworzyć całkiem nowej liturgii (por. KL 38). Przygotowanie nowych ksiąg liturgicznych było procesem trwającym zwykle kilka lat, połączonym z solidnymi studiami historycznymi, teologicznymi i pastoralnymi nad liturgią sakramentów. Badano genezę poszczególnych jej elementów (tekstów, znaków, obrzędów), aby zachować te, które są istotne, a niektóre pominąć jako właściwe dla określonego miejsca i czasu. Uwzględniano również kryteria pastoralne, aby przygotować obrzędy bardziej zrozumiałe dla wiernych, bez zbędnych powtórzeń i dostosowane do czynnego uczestnictwa całego zgromadzenia. Właściwe wykonanie Konstytucji o liturgii wymagało umiejętnego połączenia nova

" Ks. Prof. dr hab. Czesław Krakowiak, Wydział Teologii KUL, kierownik Katedry Teologii Liturgii w Instytucie Teologii Pastoralnej. 
et vetera, aby ukazać ich ścisły związek. W odnowie liturgii nie chodzi bowiem o całkowite zerwanie $\mathrm{z}$ jej dotychczasową formą, ale o to, aby dokonać jej prawdziwej odnowy, a nie niszczenia (renovatio non eversio) ${ }^{1}$.

Odnowa liturgii sakramentów dokonana po Vaticanum II związana jest ściśle z pontyfikatem Pawła VI (1963-1978). Do realizacji wskazań Sacrosanctum Concilium w dziele odnowy liturgii w Kościele, papież Paweł VI na mocy Motu proprio Sacram Liturgiam (25 I 1964)² powołał specjalną Radę do wykonania Konstytucji o liturgii - Consilium ad exsequendam Constitutionem de sacra liturgia ${ }^{3}$. Jej zadania określił następująco: "Jak wszystkim wiadomo, niejedno z zarządzeń Konstytucji nie może być w krótkim czasie wykonane, uprzednio bowiem niektóre obrzędy należy starannie rozpatrzyć i przygotować nowe księgi liturgiczne. Aby to dzieło mądrze i roztropnie przeprowadzić, ustanawiamy szczególną Komisję, której głównym zadaniem będzie dokładne wykonanie postanowień Konstytucji o liturgii świętej"4 .

${ }^{1}$ O dyskusji w czasie soboru nad treścią artykułów 73-75 Konstytucji o liturgii zob. J. Stefański, Sakrament chorych w reformie Soboru Watykańskiego II. Studium liturgiczno-teologiczne, Poznań 1988, s. 40-58.

2 Por. AAS 56 (1964), s. 139-144; zob. N. Giampietro, Il Motu proprio "Sacram Liturgiam": una rilettura a quarant'anni dalla promulgazione (1964-2004), „Ephemerides Litrugicae" 99 (2005), s. 133-150.

${ }^{3}$ Zob. A. Bugnini, La riforma liturgica (1948-1975), Roma 1983, s. 60-78; P. Marini, La nascita del "Consilium ad exsequendam Constitutionem de Sacra Liturgia. Gennaio - Marzo 1964”, „Ephemerides Litrugicae” 106 (1992), s. 289-318. O dalszych pracach Consilium zob. tenże. Il "Consilium" in piena attività in un clima favorevole (ottobre 1964 - marzo 1965)”, „Ephemerides Litrugicae” 109 (1995), s. 97-158; tenże, Attività complessiva dei gruppi di studio del "Consilium ad exsequendam Constitutionem de Sacra Liturgia Gennaio 1964 - Marzo 1965”, „Ephemerides Litrugicae” 112 (1998), s. 289-309; tenże, Il Consilium ad exesquendam Constitutionem de Sacra Liturgia (Gennaio 1964 - Marzo 1965): considerazioni generali, „Ephemerides Litrugicae” 113 (1999), s. 3-30; tenże, Il primo periodo di attività del "Consilium"; prospettive e difficoltà (marzo-giugno 1964), „Ephemerides Litrugicae” 107 (1993), s. 401-439; J. Stefański, Rola Consilium w posoborowej reformie liturgicznej, w: Tenże, Liturgia w odnowie, Gniezno 2000, s. 91-107. Prace Consilium trwały od 25 I 1964 do 9 maja 1969. W tym czasie w Consilium przygotowano 342 schematy. V. Noč, Storia della Costituzione liturgica: punti di riferimento. Nel XX anniversario della Sacrosanctum Concilium, „Notitiae" 20 (1983), s. 264.

$4, \ldots[\ldots]$ antea sint ritus quidam recognoscendi et novi liturgici libri apparendi". AAS 56 (1964), s. 140. Przewodniczącym Consilium papież mianował kard. Gaetano Lercaro arcybiskupa Bolonii († 1976), a członkami prefekta Kongregacji Obrzędów kard. Arcadia Larraona († 1973) i Paola Giobbe († 1972) z Kurii Rzymskiej, a sekretarzem Annibale Bugniniego († 1982). 
W przemówieniu do członków i konsultorów Consilium (29 X 1964) podkreślił jak trudnym zadaniem jest przygotowanie nowych ksiąg liturgicznych. Dotychczasowe formuły modlitw liturgicznych należy nie tylko przejrzeć i odnowić, ale także przygotować nowe dostosowane do współczesności, ale nie zrywając z dziedzictwem (patrimonium) i w taki sposób, by wiernie wyrażały katolicką wiarę. Należy także zachować tradycyjny styl modlitw liturgicznych, które w formie krótkiej i prostej, zrozumiałej dla uczestników, wyrażają wiarę i kult Kościoła ${ }^{5}$. W tym duchu „Rada do wykonania Konstytucji o liturgii" (Consilium) wraz z Kongregacją Kultu Bożego sukcesywnie przygotowywała księgi liturgiczne.

Jeśli w nowych księgach liturgicznych dokonano istotnych zmian w znaku sakramentalnym (materia i forma) albo w nowy sposób określono normy prawne i pastoralne dotyczące udzielania i przyjmowania sakramentów, obrzędy zostały poprzedzone specjalną konstytucją apostolską. Konstytucja apostolska jest uroczystym pismem papieża dotyczącym prawd wiary i dyscypliny w całym Kościele lub tylko w jego części ${ }^{6}$. $\mathrm{Z}$ posoborowych ksiąg liturgicznych konstytucje apostolskie zawierają: Pontyfikał rzymski De ordinatione diaconi, presbyteri et episciopi ${ }^{7}$, następnie kolejno Missale romanum ${ }^{8}$, Pontyfikał Ordo Confirmationis ${ }^{9}$ i Rytuał Ordo unctionis infirmorum ${ }^{10}$.

Prace redakcyjne nad Rytuałem Ordo unctionis infirmorum trwały osiem lat ${ }^{11}$. W tym czasie Paweł VI był na bieżąco informowany o jego kolejnych schematach ${ }^{12}$, a zwłaszcza o tym co dotyczyło najważniejszych spraw, takich jak słowa formuły sakramentalnej ${ }^{13}$, podmiotu sakramentu ${ }^{14}$, szafarza $^{15}$ i oleju chorych ${ }^{16}$. Przygotowany przez Consilium i ogłoszony dekretem Kongregacji Kultu Bożego (30 XI 1972) rytuał nosi pełny tytuł

5 ,"...] renovanadas vel integre condendas [...] catholicam doctrinam fideliter exprimant [...] brevitate et simplicitate". AAS 56 (1964), s. 994.

${ }^{6}$ Od 1909 r. konstytucje apostolskie ogłaszane są w Acta Apostiolicae Sedis.

7 Por. Pontificalis Romani recognitio (18 VI 1968). AAS 60 (1968), s. 369-373.

${ }^{8}$ Por. Missale Romanum (3 IV 1969). AAS 61 (1969), s. 217-222.

9 Por. Divinae consortium naturae (15 VIII 1971). AAS 63 (1971), s. 657-664.

10 Por. Sacram unctionem infirmorum (30 XI 1972). AAS 65 (1973), s. 5-9.

11 Por. J. Stefański, Sakrament chorych w reformie Soboru Watykańskiego II. Studium liturgiczno-teologiczne, s. 26.

12 Tamże s. 105-126.

13 Tamże s. 113-116.

14 Tamże s. 117-121

15 Tamże s. 121-122.

16 Tamże s. 114. 
Ordo unctionis infirmorum eorumque pastoralis curae $^{17}$. Ze względu na wprowadzone w nim poważne zmiany w stosunku do Rytuału Rzymskiego z 1925 r. konieczna była konstytucja apostolska. Paweł VI ogłosił w niej i zatwierdził nie tylko nowe obrzędy, ale również obowiązujące odtąd normy prawne dotyczące sakramentu namaszczenia chorych ${ }^{18}$.

Pierwszy schemat konstytucji przygotowany przez P. M. Gy został przesłany do Kongregacji Nauki Wiary 28 marca 1972 roku. Następnie był dyskutowany (4 V 1972) na wspólnym zebraniu Kongregacji Kultu Bożego, Kongregacji Nauki Wiary, Kongregacji Dyscypliny Sakramentów i Kongregacji ds. Duchowieństwa ${ }^{19}$. Uzgodniony wtedy tekst 28 czerwca 1972 r. Kongregacja Nauki Wiary przesłała do Sekretariatu Stanu. Po dokonaniu poprawek języka łacińskiego przez latynistów Sekretariat Stanu przesłał 13 lipca projekt konstytucji do Kongregacji Dyscypliny Sakramentów. Paweł VI podpisał ostateczną wersję konstytucji Sacram unctionem infirmorum 30 listopada 1972 roku $^{20}$. Zawiera ona syntezę nauki Kościoła o sakramencie namaszczenia chorych na podstawie źródeł biblijnych, liturgicznych i zwyczajnego nauczania Kościoła ${ }^{21}$.

\section{ISTNIENIE SAKRAMENTU NAMASZCZENIA CHORYCH}

W Konstytucji Sacram unctionem infirmorum można wyróżnić trzy części. W pierwszej części Paweł VI odwołuje się do Pisma Świętego i nauczania Kościoła katolickiego, podkreślając, że namaszczenie chorych jest jednym z siedmiu sakramentów Nowego Testamentu, ustanowionym przez Chrystusa. Przytacza orzeczenie Soboru Trydenckiego, że wspomina o nim św. Marek 6,13 (apud Marcum insinuatum) „Wyrzucali też wiele złych duchów oraz wielu chorych namaszczali olejem i uzdrawiali".

17 Typis Polyglottis Varticanis 1972.

${ }^{18}$ Na podkreślenie zasługuje już sam fakt, że papież konsekwentnie nazywa ten sakrament unctio infirmorum. Nazwa extrema unctio występuje w konstytucji tylko wtedy, gdy odwołuje się do dawnych dokumentów Kościoła.

19 Por. A. Bugnini, La riforma liturgica, s. 669-670.

${ }^{20}$ Zob. AAS 65 (1973), s. 5-9; zob. A. G. Martimort, Commento pastorale alla Costituzione Apostolica sull'Unzione degli infermi, „Ambrosius” 49 (1973), s. 115-120; G. Oury. L'onction des malades. Constitution Apostolique "Sacram Unctionem infirmorum", "Esprit et Vie" 83 (1973), s. 145-149.

${ }^{21}$ Por. A. Bugnini, La riforma liturgica, s. 671-672. 
Następnie jest polecany wiernym i ogłoszony (fidelibus commendatum et promulgatum) przez Jakuba Apostoła Jk 5,14-1522.

Praktykę udzielania namaszczenia chorych potwierdza Tradycja Kościoła na Wschodzie i na Zachodzie ${ }^{23}$. Paweł VI powołuje się na list Innocentego I z 416 r. do Decencjusza biskupa Gubbio, w którym cytuje on list św. Jakuba 5,14-15 i wyjaśnia, że namaszczenie chorych olejem poświęconym przez biskupa jest prawdziwym sakramentem Kościoła. Udzielają go prezbiterzy, może udzielać go także biskup, ale nie mogą przyjmować go pokutnicy. Tym poświęconym olejem mogą namaszczać się także sami wierni ${ }^{24}$. Istnienie sakramentu namaszczenia chorych potwierdzają także liczne źródła liturgiczne. Papież powołuje się na modlitwę poświęcenia oleju chorych Emitte, Domine, Spiritum Sanctum tuum Paraclitum, która m.in. w Sakramentarzu Gregoriańskim jest włączona do Modlitwy eucharystycznej, a także zawiera ją Pontyfikał rzymski ${ }^{25}$.

\section{SAKRAMENT NAMASZCZENIA CHORYCH DO II SOBORU WATYKAŃSKIEGO}

W drugiej części konstytucji Paweł VI wyjaśnia motywy i zasady odnowy liturgii sakramentu namaszczenia chorych w nawiązaniu kolejno do nauczania Soboru Florenckiego, Trydenckiego i II Watykańskiego. Sobór Florencki (1439) w Dekrecie dla Ormian, cytując List św. Jakuba 5,14-15, stwierdzał, że piątym sakramentem jest extrema unctio. Sobór ten określił również jego materię, podmiot, formułę sakramentalną i szafarza oraz główny skutek. Materią jest olej z oliwek pobłogosławiony przez biskupa. Podmiotem jest jedynie chory w niebezpieczeństwie śmierci (nisi infirmo de cuius morte timetur, dari non debet). Formułę sakramentu stanowią słowa: Przez to święte namaszczenie i swoje dobrotliwe miłosierdzie niech ci odpuści

22 Por. Denz 1695; 1716; BF VII, 513; por. BF VII, 516.

${ }^{23}$ W Kościele greckim sakrament namaszczenia określa się po prostu „olej” (elaion) lub "olej święty (to hagion elaion), „olej modlitwy” i „olej zbawienia” (euchelaion). E.Ch. Suttner, Die Krankensalbung (das "Öl des Gebets") in den Altorientalischen Kirchen, „Ephemerides Litrugicae“ 89 (1975), s. 371.

24 Por. Denz 216; BF VII, 510.

25 Por. Ordo bednedicendi oleum catechumenorum et infimorum et conficiendi chrisma, Typis Polyglottis Vaticanis 1971, s. 11-12. 
Pan, cokolwiek zawiniłeś wzrokiem ${ }^{26} . .$. , którą powtarza się przy namaszczaniu poszczególnych zmysłów. Namaszcza się w następujących miejscach: oczy ze względu na wzrok, uszy ze względu na słuch, nozdrza jako siedzibę zmysłu powonienia, usta ze względu na smak i mowę, ręce ze względu na dotyk, nogi ze względu na chodzenie, okolicę nerek ze względu na przyjemność z nimi związaną. Szafarzem namaszczenia chorych jest kapłan (sacerdos). Skutkiem zaś jest uzdrowienie duszy (mentis sanatio), a o ile jest to dla niej pożyteczne, także uzdrowienie ciała ${ }^{27}$.

Paweł VI odwołuje się następnie do doktryny Soboru Trydenckiego, który na XIV Sesji (1551) określił naukę Kościoła katolickiego o boskim ustanowieniu sakramentu namaszczenia chorych (extremae unctionis), jego skutkach, szafarzu, materii i czasie udzielania go chorym ${ }^{28}$. Sobór ten także cytuje List św. Jakuba 5,14-15, jako podstawę istnienia sakramentu. Podkreśla również, że namaszczenie poświęconym olejem w sposób doskonały ukazuje łaskę Ducha Świętego, która niewidzialnie namaszcza duszę chorego ${ }^{29}$.

Na szczególną uwagę zasługuje wyjaśnienie Soboru Trydenckiego, czym jest istota (res) tego sakramentu. A jest nią "łaska Ducha Świętego". Namaszczenie nim usuwa winy, jeśli są jeszcze do odpokutowania, oraz pozostałości grzechu. Sobót Trydencki, za św. Tomaszem z Akwinu, łączy ściśle sakrament namaszczenia chorych z sakramentem pokuty jako jego dopełnienie, a nawet dopełnienie całego życia chrześcijańskiego ${ }^{30}$. Inne skutki namaszczenia chorych polegają na tym, że sakrament ten przynosi pociechę duszy i umacnia chorego, wzbudzając w nim wielką ufność w Boże miłosierdzie. Dzięki temu chory łatwiej znosi dolegliwości choroby i skuteczniej opiera się pokusom szatana. Jeśli to jest przydatne do zbawienia duszy, niekiedy również odzyskuje zdrowie ${ }^{31}$.

Sobór ten, zgodnie z Listem św. Jakuba, określił, że właściwymi szafarzami namaszczenia chorych są ministri Ecclesiae, tzn. presbyteri. Jed-

26 „Per istam unctionem et suam pissimam misericordiam indulget tibi Dominus quidquid deliqusi per visum...". Denz 1324.

27 Por. Denz 1325.

${ }^{28}$ Por. Denz 1694-1700. Zob. A. Duval, L'extręme onction au Concile de Trenet. Sacrement des mourant ou sacrément des malade?, LMD 1970 nr 101, s. 127-172.

${ }^{29}$, ,...] unctio aptissime Spiritus Sancti gratiam, quam invisibiliter anima aegrtotantis inungitur, repraesenatat...". Denz 1695.

30, ,[... totius christinae vitae consummativum". Denz 1694; por. Św. Tomasz, Summa contra gentiles IV, 73 .

31 Por. Denz 1696; BF VII, 514. 
nocześnie wyjaśnił, że są nimi albo biskupi, albo wyświęceni przez nich przez włożenie rąk sacerdoti (por. 1 Tm 4,14), nie zaś starsi wiekiem czy też znakomitsi wśród ludu ${ }^{32}$.

Sobór Trydencki określa, że podmiotem sakramentu namaszczenia są chorzy, a zwłaszcza ci, którzy niebezpiecznie chorują, tak iż wydaje się, że znajdują się u kresu życia. Z tej racji namaszczenie chorych bywa nazywane sakramentem odchodzących $z$ tego świata (sacramentum exeuntium), czyli umierających. Sobór przewiduje jednocześnie możliwość ponownego przyjęcia sakramentu, jeśli po wyzdrowieniu wierny znajdzie się w podobnej sytuacji zagrożenia życia ${ }^{33}$.

\section{SAKRAMENT NAMASZCZENIA CHORYCH W VATICANUM II I KONSTYTUCJI SACRAM UNCTIONEM INFIRMORUM}

Przechodząc do nauczania II Soboru Watykańskiego o sakramencie namaszczenia chorych, Paweł VI przytacza tekst nr 73 Konstytucji o liturgii ${ }^{34}$, w którym odnośnie do nazwy extrema unctio sobór stwierdza, że lepiej określać go unctio infirmorum, gdyż nie jest on sakramentem przeznaczonym jedynie dla tych, którzy znajdują się w niebezpieczeństwie utraty życia ${ }^{35}$. Odpowiedni czas przyjęcia tego sakramentu jest wtedy, gdy

32 Por. Denz 1697; BF VII, 515.

33, ,...] esse hanc unctionem infirmis adhibendam, illis vero praesertim, qui tam periculose decumbunt, ut in exitu viae constituti vedantur, unde et sacramentum exeuntium nuncupatur". Denz 1698; BF VII, 515.

${ }^{34} \mathrm{~W}$ Schemacie Konstytucji o liturgii zrywa się z nazwą extrema unctio na rzecz unctio infirmorum uzasadniając, że z istoty swej nie jest to sakrament umierających, lecz ciężko chorych: „Sacramentum quo communiter extrema unctio nuncupatur, deinceps Unctio infirmorum vocabitur; nam non est per se sacramentum morientium, sed graviter aegrotantium". Acta Synodalia vol. I, pars II s. 285. Dyskusja nad problemem nazwy sakramentu zob. tamże s. 252-383. W konsekwencji osiągnięto kompromis, zamiast jednoznacznego określenia unctio infirmorum, zachowano dawną nazwę extrema unctio zaznaczając, że bardziej stosowna jest nazwa unctio infirmorum „Extrema unctio, quae etiam et melius Unctio infirmorum vocari potest" KL 73. Zdaniem I. Różyckiego w nazwie "ostatnie namaszczenie" chodzi o ostatnie w kolejności namaszczenie, a nie o namaszczenie $\mathrm{w}$ ostatnich chwilach życia i dlatego sobór tę nadawę zachował. Teologiczne następstwa soborowej Konstytucji o liturgii, "Studia Theologica Varsaviensia" 3 (1965), s. 21-22.

${ }^{35} \mathrm{~W}$ Kościele łacińskim sakrament ten różnie określano: oleum sanctum, oleum chrismatio, sacra unctio, unctio infirmorum. Od średniowiecza przyjęły się nazwy extrema unctio i sacramentum exeuntium, praeparatio ad gloriam. E. Melia, Le sacrement de l'onction 
choremu zaczyna grozić niebezpieczeństwo śmierci z powodu choroby lub starości. Drugim dokumentem soboru, na który powołuje się Paweł VI, jest Konstytucja o kościele nr 11 o namaszczeniu chorych w praktyce Kościoła i określa je jako uctio infirmorum (por. KK 28 ) $^{36}$.

Dokonując rewizji obrzędów sakramentu namaszczenia, Paweł VI stwierdza, że tę naukę Kościoła należy uwzględnić przy odnowie liturgii namaszczenia chorych, aby dostosować ją do naszych potrzeb i zmienić to, co może być zmienione, w duchu zasad zawartych w nr. 1 Konstytucji o liturgii. Chodzi więc o dostosowanie "do potrzeb naszych czasów”, tego, co w liturgii może podlegać zmianom i tak ją odnowić, aby przyczyniła się do większego rozwoju życia chrześcijańskiego ${ }^{37}$.

Odnosząc się do obrzędów sakramentu, Paweł VI stwierdza, że w przeszłości namaszczano różne części ciała, była także różna liczba namaszczeń i stosowano różne formuly im towarzyszące. Potwierdzają to liczne rytuały wielu Kościołów. W Kościele Rzymskim od średniowiecza, namaszczając zmysły stosowano formułę „Przez to święte namaszczenie..." ${ }^{\prime 38}$.

W liturgii sakramentów szczególną rolę odgrywa formuła sakramentalna. Papież dokonuje jej zamiany w taki sposób, (ita mutare censuimus), aby zostały do niej włączone słowa z Listu św. Jakuba, a przez to jaśniej wyrażone skutki sakramentu. Papież uwzględnił także prośby wielu biskupów z tych krajów, w których olej z oliwek jest trudno dostępny, aby zastąpić go innym olejem roślinnym, podobnym do oleju

des malades dans son développement historique et quelque considération sur la pratique actuelle, w: Maladie et la mort dans la liturgie, s. 195-201-216. J.E. Lengeling, Todesweihe oder Krankensalbung, "Liturgisches Jahrbuch” 21 (1971), s. 193-213. Nazwę extrema unctuio utrwalił Sobór Trydencki, ale używa także określenia unctio infirmorum i unctio (Denz 1694-1700; 1716-1719). Pius XII w encyklice Mystici Corporis (1943) pisze o sacra infiormorum unctio: „Ac postremo hominibus ad mortem oblanguescentibus praesto est pia Mater Ecclesia quae per sacram infirmorum unctionem...”. AAS 35 (1943), s. 202; a w encyklice Mediator Dei (1947) o sacra probalsamum. AAS 39 (1947), s. 52. Na temat dyskusji w Consilium nad nazwą sakramentu namaszczenia i jego przeznaczeniem oraz możliwościami ponownego przyjęcia zob. J. Stefański, Sakrament chorych w reformie Soboru Watykańskiego II, s. 49-47; 53-57.

${ }^{36}$ Dekret o życiu i posłudze prezbiterów nr 5 mówi o oleum infirmorum. Zob. A. Knauber, Sakrament der Kranken. Terminologische Beobachtungen zum "Ordo Unctionis Infirmorum”, „Liturgisches Jahrbuch“ 23 (1973), s. 226-229.

${ }^{37}$ Prace nad liturgią namaszczenia chorych szczegółowo przedstawia J. Stefański, Sakrament chorych w reformie Soboru Watykańskiego II, s. 74-122.

${ }^{38}$ Denz 1324. 
z oliwek. Wyraził również wolę uproszczenia samego sposobu udzielania namaszczenia, ograniczając liczbę namaszczeń na ciele chorego.

W końcowej, trzeciej, części konstytucji papież Paweł VI uroczyście zatwierdza odnowione obrzędy sakramentu namaszczenia chorych i określa sposób jego udzielania w obrządku łacińskim. Sakramentu tego udziela się „niebezpiecznie chorym” (periculose aegrotantibus), namaszczając ich na czole i na rękach olejem z oliwek albo innym olejem roślinnym, w sposób właściwy poświęconym, wypowiadając tylko jeden raz słowa formuły sakramentalnej. Odtąd będzie obowiązywała następująca formuła: „Per istam sanctam unctionem ett suam pissimam misericordiam adiuvet te Dominus gratia spiritus Sancti, ut a pecctatis liberatum te salvet atque propotuus allevet" ${ }^{\prime \prime 2}$.

W Konstytucji tej papież podaje również sposób postępowania w sytuacjach nadzwyczajnych. W przypadku konieczności wystarczy jedno namaszczenie na czole lub innej części ciała $\mathrm{z}$ formułą sakramentalną. Jeśli po namaszczeniu chory powrócił do zdrowia i potem znów zachorował, albo $\mathrm{w}$ tej samej chorobie nastąpiło znaczne pogorszenie się jego stanu zdrowia, można ponownie udzielić sakramentu namaszczenia.

Po tych wyjaśnieniach Paweł VI uroczyście aprobuje przygotowany przez Kongregację Kultu Bożego rytuał Ordo unctionis infirmorum eorumque pastoralis curae ${ }^{40} \mathrm{i}$ unieważnia całkowicie lub częściowo pewne postanowienia Codex Iuris Canonici oraz inne przepisy dotychczas obowiązujące. Te natomiast, które nie są sprzeczne z Ordo unctionis, nadal zachowują ważność i obowiązują. Dawne obrzędy namaszczenia można stosować do końca 1973 roku. Nowe Ordo unctionis w języku lacińskim obowiązuje po jego publikacji, ale od 1 stycznia 1974 należy praktykować tylko nowe obrzędy, które $\mathrm{w}$ językach narodowych mają przygotować konferencje biskupów. Papież odwołuje jednocześnie inne konstytucje i rozporządzenia odnoszące się do sakramentu namaszczenia chorych, a wydane przez jego poprzedników.

39 AAS 65 (1973), s. 8. Tłum. pol. „Przez to święte namaszczenie niech Pan w swoim nieskończonym miłosierdziu wspomoże ciebie łaską Ducha Świętego. Amen. Pan, który odpuszcza ci grzechy, niech cię wybawi i łaskawie po9dźwignie. Amen". Sakramenty chorych. Obrzędy i duszpasterstwo, Katowice 1978, s. 72, nr 99.

${ }^{40}$ Rytuał ten został ogłoszony 7 grudnia 1972 r. dekretem Kongregacji Kultu Bożego Infirmis cum Eccelsia. AAS 65 (1973), s. 275-276. Zob. P.M. Gy, Le nouveau rituel des malades, „Notitiae” 9 (1973), s. 108-118; tenże, Le nouveau rituel des malades, „La Maison-Dieu" 113 (1973), s. 29-49. 
Wiele postulatów dotyczących sakramentu namaszczenia chorych zgłaszanych przez biskupów na II Sobór Watykański i dyskusja w czasie jego trwania oraz prace teologów zostały uwzględnione najpierw w soborowych dokumentach: Konstytucji o liturgii i Konstytucji o Kościele. Wprawdzie jeszcze Konstytucja o liturgii sakrament namaszczenia chorych nazywa extrema unctio, z zaznaczeniem, że lepsza jest nazwa unctio infirmorum, ale w następnych dokumentach określenie „ostatnie namaszczenie" już nie występuje. Wynikają stąd ważne konsekwencje teologiczne i pastoralne. Odtąd sakrament ten nie jest przeznaczony jedynie dla tych, którzy są w niebezpieczeństwie śmierci, lecz dla niebezpiecznie chorych oraz wiernych w podeszłym wieku i przed poważną operacją. Jego głównym celem nie jest również gładzenie grzechów, o czym mówiła dawna formuła sakramentalna oraz namaszczanie zmysłów (narzędzi grzechu), ale duchowa pomoc w czasie choroby. W tym duchu Consilium i Kongregacja Kultu Bożego przygotowała rytuał Ordo unctionis infirmorum. Ponieważ zawiera on wiele ważnych zmian $\mathrm{w}$ stosunku do dawnego rytuału De extrema unctione, ich wprowadzenie uzasadnia i aprobuje Paweł VI w Konstytucji Apostolskiej Sacram unctionem infirmorum. Za najważniejsze należy uznać: nową formułę sakramentalną, która przede wszystkim podkreśla, że $\mathrm{w}$ tym sakramencie choremu pomaga łaska Ducha Świętego i włączenie do niej słów z listu św. Jakuba, że Pan go „wybawi i łaskawie podźwignie”; oraz namaszczenie jedynie czoła i rąk. Możliwość używania do namaszczenia innego oleju roślinnego, a nie tylko z oliwek, jest odpowiedzią Kościoła na postulaty biskupów. Konstytucja Sacram unctionem infirmorum utrwala także nazwę sakramentu „namaszczenie chorych” i przez to jednoznacznie określa, że jest on przeznaczony na czas poważnej choroby, a nie jedynie $\mathrm{w}$ bliskim niebezpieczeństwie śmierci.

\section{STRESZCZENIE}

Odnowiony po Vaticanum II rytuał sakramentu namaszczenia chorych (Ordo unctionis infirmorum) zawiera wiele istotnych zmian w porównaniu z rytuałem potrydenckim. Dlatego zawiera Konstytucję Apostolską Pawła VI Sacram unctionem infirmorum, w której papież przypomina nauczanie i praktykę Kościoła dotyczące tego sakramentu. Następnie uzasadnia ważne zmiany wprowadzone w nowym rytuale: podmiot sakramentu (poważnie chory i osoby w podeszłym wieku - senes); znak 
sakramentalny: materia - nie tylko olej z oliwek, ale także inne oleje roślinne; forma sakramentu, która podkreśla jego skutki - pomoc łaską Ducha Świętego, zbawienie i podźwignięcie chorego. Papież odchodzi od nazwy extrema unctio i wprowadza nową nazwę unctio infirmorum.

Słowa kluczowe: namaszczenie chorych, konstytucja Sacram unctionem infirmorum, Paweł VI

\author{
Abstract: Paul VI Apostolic Constitution on the Sacrament of Anointing \\ of the Sick
}

A post-Vatican II renewed ritual of the sacrament of the anointing of the sick (Ordo unctionis infirmorum) contains many significant changes compared with the post-Tridentine ritual. The new ritual is prefaced by the Apostolic Constitution Sacram unctionem infirmorum of Paul VI in which the Pope recalls the teaching and practice of the Church concerning the sacrament. Furthermore, it goes on to outline the significant changes and different emphasis introduced in the new ritual. The following are some of these: the object of the sacrament (in danger of death from sickness or old age - senses); sacramental sign; the matter - olive oil may be used but so too may other oils from different plants; the form of the sacrament, which highlights its effects - it is help given by the grace of the Holy Spirit, it is an aid to our salvation and is to be used to pray for restoration and healing of the sick. The Pope significantly departs from the name extrema unction, by which name the sacrament had been previously known, to introduce a new name, unctio infirmorum. Paul IV

Key words: anointing of the sick, constitution Sacram unctionem infirmorum, 
